\title{
A partially ossified falx cerebri
}

\author{
A. Zandian1 , P. Clarke1, R.S. Tubbs¹,3, M. Loukas ${ }^{1,2}$ \\ ${ }^{1}$ Department of Anatomical Sciences, St. George's University, School of Medicine, Grenada, West Indies \\ ${ }^{2}$ Department of Anatomy, Varmia and Mazuria University, Olsztyn, Poland \\ ${ }^{3}$ Paediatric Neurosurgery, Children's Hospital, Birmingham, Alabama, United States
}

[Received 9 October 2013; Accepted 19 November 2013]

\begin{abstract}
During a routine faculty prosection of the head and neck region of an adult female cadaver, a partial ossification of the falx cerebri was found. Ossification of other dural areas or regions of the body were not found. In addition, the brain and remaining organs appeared to be grossly normal. Reports of partial ossification of the falx cerebri are still rare and while certain pathologies such as nevoid basal cell carcinoma syndrome typically present with ossification of the falx on radiographs, the causal relationship of such an abnormality remains unclear. (Folia Morphol 2014; 73, 3: 363-365)
\end{abstract}

Key words: cranium, meninges, dura mater, falx cerebri, ossification

\section{INTRODUCTION}

Anatomical variations in the cerebral venous sinuses are unpredictable and clinically significant. Accounts of ossification of both the pachymeninges and leptomeninges have been cited in the literature $[1,3,5,10,35]$. While common in many animals, bony ossification of the meninges is exceedingly rare in humans. Cases of calcification, chondromas, and osteopetrosis have been reported in the literature yet very rarely involve the falx cerebri (FC) $[6,16,17$, 20, 22-24, 34, 36].

We present a case in which partial ossification of the FC was observed without abnormal ossification in other intracranial dural components, or in the rest of the body.

\section{CASE REPORT}

We present a case of a partially ossified FC in a 70-year-old female human cadaver, who died of acute myocardial infarction. Further examination of the patient's medical history revealed no evidence of other concurrent medical conditions. The case was discovered during a faculty [ML, RST] head and neck prosection in the Department of Anatomical Sciences at St. George's University during the summer term of 2006. The vast ossified portion of the FC was located at its anterior one third, with the addition of 2 focal areas of calcification along the middle and posterior one third of this structure (Figs. 1, 2). Further dissection revealed only involvement of the FC. The falx cerebelli, tentorium cerebelli, leptomeninges, and other dural components were spared. The inferior sagittal sinus was injected with red latex and found to be obstructed from the ossification at its distal part. No other anomalies were found. With these observations in mind, dissection continued in order to identify possible malignancies that could metastasize to the FC and cause ossification.

No abnormal or visible masses were found in the thoracic, abdominal, or pelvic cavities. We also examined the distal oesophagus, cardioesophageal junction, salivary gland and lungs, which all proved to appear normal $[33,38]$. Lymph nodes, in general, appeared to be small and normal with gross inspection. There were no additional signs of Gorlin-Goltz syndrome, as the specimen did not appear to have any visible tumours, odontogenic keratocysts, or other developmental anomalies. 


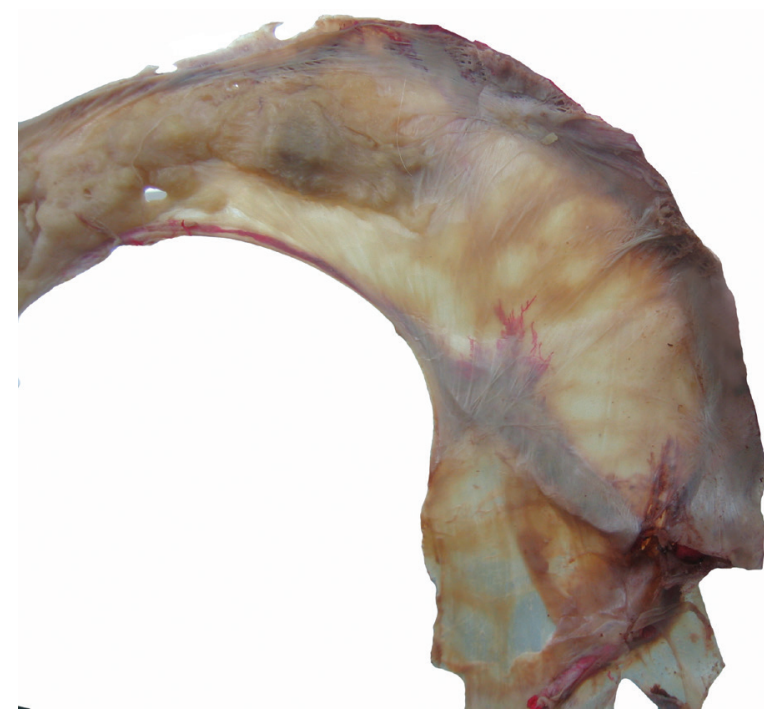

Figure 1. The partially ossified falx cerebri found in our specimen.

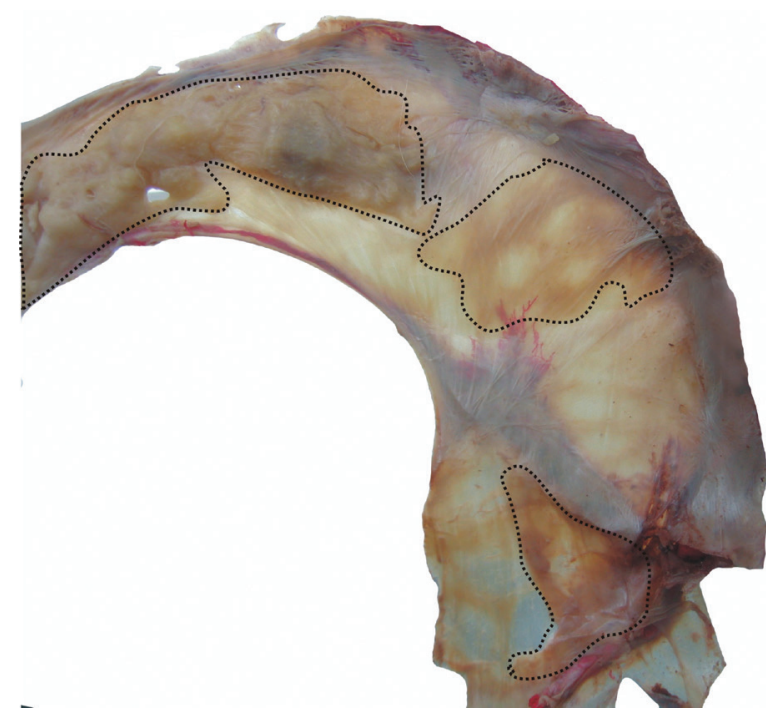

Figure 2. The areas of ossified falx cerebri (dotted lines).

\section{DISCUSSION}

When describing anatomical variations, a comprehensive search of the literature is necessary for comparison with other research in order to establish the prevalence of the variation and to determine any potential clinical consequences. Reports of ossification of the meninges are found infrequently in the literature. In an magnetic resonance imaging (MRI) study of 3,000 patients, incomplete ossification of the FC was noted in 12 individuals [28]. In another study of 100 post-mortem cadavers, bony islands were found 11 times in the anterior FC [31]. Interestingly, only 1 case of complete ossification of the
FC has been reported in the literature [35]. Sporadic ossification of the $\mathrm{FC}$ is reasonable as haemorrhage, damage, degeneration, or inflammation may trigger ossification in multipotential mesenchymal cells found in this region [2].

Ossification of the tentorium cerebelli is common in many subhuman species including porpoises, dolphins, dogs, cats and wallabies [15]. In porpoises and dolphins, tentorium cerebelli ossification incorporates the posteroinferior portion of the FC. Osteogenic capabilities in the ectomeningeal-dermal layer have been hypothesised to contribute to the ossification of the tentorium cerebelli in these mammals [15].

Although some anatomical data are present in the literature, there are few reports that address any clinical significance of this variation. It has been reported that patients with nevoid basal cell carcinoma syndrome (Gorlin-Goltz syndrome), hypertelorism, brachyolmia, pseudoxanthoma elasticum, renal failure, chondrocalcinosis, prostatic adenocarcinoma, and some endocrine disorders have an increased prevalence of FC ossification [4, 7, 8, 20, 29, 30].

Although idiopathic calcification of the FC can reach up to $7 \%$ of the normal adult population [11, 27], several studies have found that calcification of the FC is a common radiological finding in nevoid basal cell carcinoma, with rates ranging from $65 \%$ to $79 \%$ $[12-14,19,25]$. It thus may be possible to use radiologic calcification of the FC on computed tomography or MRI as a method of early diagnosis for nevoid basal cell carcinoma, as has already been proposed for atlanto-occiptal ligament calcification [18].

The ossified FC may also become the site of metastatic involvement or leukemic infiltration, increasing a patient's likelihood of developing cancer in this region [2, 9]. Giant-cell bone tumours developing from an ossified FC have been reported in case reports [2]. In previous years, partial ossification of the FC has been associated with pregnancy, rickets, epilepsy, syphilis and increased intracranial pressure; however, these correlations were later proven to be unfounded [3]. One study prepared cranial MRI on 13 patients with the adult onset myotonic dystrophy which found partial ossification of the FC in 2 patients [21]. Calcium content in the FC has been noted to increase on aging, but the relationship with complete ossification and age has not been established [3, 32]. No absolute clinical significance has been found in patients with ossification of the FC; however, this ossification has been confused with myelometapla- 
sia, dural metastases, leukemic infiltration, falcine osteosarcoma, and vascular lesions [26, 37].

Despite the lack of evidence for clinical effects, an ossified FC could produce problems in the displacement of brain tissue in the event of a unilateral increase in intracranial pressure as seen in different types of herniation [35]. Additionally, as seen in our specimen, obstruction of the superior sagittal sinus could lead to increased intracranial pressure with potentially fatal results. In our case report, partial ossification of the FC was observed without abnormal ossification in the dural components intracranially, or in the rest of the body. There were no indicators for metastatic growth of carcinoma within the ossified region. Future studies focusing on nevoid basal cell carcinoma syndrome and other related pathologies may need to closely monitor correlations with calcification and ossification of the FC in hopes of coming closer to finding a causal relationship between the two.

\section{REFERENCES}

1. Al-Motabagani M, Haroun H, Meguid EA (2004) Calcification and ossification of the convexity of the falx cerebri and related subdural space in human cadavers. Neruosciences (Riyadh), 9: 261-264.

2. Batnitzky S, Powers JM, Schechter MM (1974) Falx "calcification" does it exist? Neuroradiology, 7: 255-260.

3. Bruyn GW (1963) Calcification and ossification of the cerebral falx and superior longitudinal sinus. Psychiatr Neurol Neurochir, 66: 98-119.

4. Cohen MM, Richieri-Costa A, Guion-Almeida ML, Saavedra D (1995) Hypertelorism: interorbital growth, measurements, and pathogenetic considerations. Int J Oral Maxillofac Surg, 24: 387-395.

5. Debnarth J, Satija L, George RA, Vaidya A, Sen D (2009) Computed tomographic demonstration of unusual ossification of the falx cerebri: a case report. Surg Radiol Anat, 31: 211-213.

6. Erdogan S, Zorludemir S, Erman T, Akgul E, Ergin M, Ildan F, Bagdatoglu H (2006) Chondromas of the falx cerebri and dural convexity: report of two cases and review of the literature. J Neurooncol, 80: 21-25.

7. Fallon MD, Ellerbrake D, Teitelbaum SL (1982) Meningeal osteomas and chronic renal failure. Hum Pathol, 13: 449-453.

8. Fink LH (1979) Metastasis of prostatic adenocarcinoma simulating a falx meningioma. Surg Neurol, 12: 253-258.

9. Husain J, Jarial MS, Muller J, Kocoshis TA (2002) Giant-cell tumor of bone arising from the falx cerebri. A case report. J Submicrosc Cytol Pathol, 34: 67-76.

10. Kaufman AB, Dunsmore RH (1971) Clincopathological considerations in spinal meningeal calcification and ossification. Neurology, 21: 1243-1248.

11. Kieffer SA, Gold LHA (1974) Intracranial physiologic calcifications. Semin Roentgenol, 9: 151-162.

12. Kimonis VE, Goldstein AM, Pastakia B, Yang ML, Kase R, Digiovanna JJ, Bale AE, Bale SJ (1997) Clinical manifestations in 105 persons with nevoid basal cell carcinoma syndrome. Am J Med Genet, 69: 299-308.

13. Kimonis VE, Mehta SG, Digiovanna JJ, Bale SJ, Pastakia B (2004) Radiological features in 82 patients with nevoid basal cell carcinoma (NBCC or Gorlin) syndrome. Genet Med, 6: 495-502.

14. Kimonis VE, Singh KE, Zhong R, Pastakia B, Digiovanna JJ, Bale SJ (2013) Clinical and radiological features in young individuals with nevoid basal cell carcinoma syndrome. Genet Med, 1: 79-83.

15. Klintworth GK (1968) The comparative anatomy and phylogeny of the tentorium cerebelli. Anat Rec, 160: 635-642.

16. Kretzschmar HA, Eggert HR, Beck U, Furmaier R (1989) Intracranial chondroma. Case report. Surg Neurol, 32: $121-125$.

17. Lacerte D, Gagne F, Copty M (1996) Intracranial chondroma. Report of two cases and review of the literature. Can J Neurol Sci, 23: 132-137.

18. Leonardi R, Santarelli A, Barbato E, Ciavarella D, Bolouri S, Harle F, Palazzo G, Lo Muzio L (2010) Atlanto-occipital ligament calcification: a novel sign in nevoid basal cell carcinoma syndrome. Anticancer Res, 30: 4265-4268.

19. Lo Muzio L, Nocini PF, Savioa A, Consolo U, Procaccini M, Zelante L, Pannone G, Bucci P, Dolci M, Bambini F, Solda P, Favia G (1999) Nevoid basal cell carcinoma syndrome. Clinical findings in 37 Italian affected individuals. Clin Genet, 55: 34-40.

20. Masson G, Thomas P, Gasquet C, Bontoux D (1985) Is calcification of the falx cerebri a sign of chondrocalcinosis? Presse Med, 14: 227-228.

21. Miaux Y, Chiras J, Eymard B, Lauriot-Prevost MC, Radvanyi $H$, Martin-Duveneuil N, Delaporte C (1997) Cranial MRI findings in myotonic dystrophy. Neuroradiology, 39: 166-170.

22. Obrador S, Soto $F(1953)$ Frontal chondroma of the falx cerebri. Rev Clin Esp, 51: 257-260.

23. Ozgen T, Pamir MN, Akalan N, Bertan V, Onol B (1984) Intracranial solitary chondroma. Case report. J Neurosurg, 61: 399-401.

24. Patel PJ, Kolawole TM, al-Mofada S, Malabarey TM, Hulailah A (1992) Osteopetrosis: brain ultrasound and computed tomography findings. Eur J Pediatr, 151: 827-828.

25. Pruvost-Balland C, Gorry P, Boutet N, Magnaldo T, Mamelle G, Marguilis A, Kolb F, Duvillard P, Spatz A, Brugieres L, Chompret A, Avril MF (2006) Clinical and genetic study in 22 patients with basal cell nevus syndrome. Ann Dermatol Venereol, 133: 117-123.

26. Ruge JR, Russell EJ, Levy RM (1990) Mineralization of the falx cerebri simulating interhemispheric vascular anomalies on MR imaging. J Neurosurg, 72: 971-974.

27. Saldino RM, Di Chiro G (1974) Tentorial calcification. Radiology, 111: 207-210.

28. Sands SF, Farmer P, Alvarez O, Keller IA, Gorey MT, Hyman RA (1987) Fat within the falx: mr demonstration of falcine bony metaplasia with marrow formation. J Comp Assisted Tomograph, 11: 602-605.

29. Satoh M, Fukazawa H, Yagawa K, Endo H, Suzuki A (1977) Two cases of nevoid basal cell carcinoma syndrome. Acta Pathol Jpn, 27: 713-727.

30. Shohat M, Lachman R, Gruber HE, Rimoin DL (1989) Brachyolmia: radiographic and genetic evidence of heterogeneity. Am J Med Genet, 33: 209-219.

31. Teir H, Ohela K (1956) Über Verhärtungen in der dura (auf grund eines gerichtsmedizinischen falls). Dtsch $X$ ges gerichtl Med, 45: 488-492.

32. Tohino $Y$, Tohino S, Minami T, Moriwake $Y$, Yamada M, Furuta K, Yamada M, Haga S, Yamamoto H (2000) Differences in the Mineral Contents Between Falx Cerebri and Tentorium Cerebelli. Biological Trace Element Research, 78: 43-52.

33. Tot $T$ (1999) Adenocarcinomas metastatic to the liver. The value of cytokeratins 20 and 7 in the search for unknown primary tumors. Cancer, 85: 171-177.

34. Trelles JO, Benigno S, Tello A (1963) Calcifications of the falx cerebri. Presse Med, 71: 1845-1848.

35. Tubbs RS, Kelly DR, Lott R, Salter EG, Oakes WJ (2006) Complete ossification of the human falx cerebri. Clin Anat, 19: 147-150.

36. von Wrangell U, Fassbender CW (1974) Calcification and ossification of the falx cerebri. Fortschr Geb Rontgenstr Nuklearmed, 121: 550-555.

37. Wang AM, Fitzgerald TJ, Lichtman AH, Power TC, Zamani AA, Haykal HA, Rumbaugh CL (1986) Neuroradiologic features of primary falx osteosarcoma. AJNR, 7: 729-732.

38. Wauters CCAP, Smedts F, Gerrits LGM, Bosman FT, Ramaekers FCS (1995) Keratins 7 and 20 as diagnostic markers of carcinomas metastatic to the ovary. Hum Pathol, 26: 852-855. 